\title{
Squamous cell carcinoma transformation in mature cystic teratoma of the ovary: a systematic review
}

Congcong Li ${ }^{1 \dagger}$, Qing Zhang ${ }^{1,2+}$, Siying Zhang ${ }^{1}$, Ruifen Dong ${ }^{1}$, Chenggong Sun ${ }^{1}$, Chunping Qiu', Zhiwei Zhang ${ }^{1}$, Xingsheng Yang ${ }^{1}$ and Beihua Kong ${ }^{1,2^{*}}$

\begin{abstract}
Background: $0.17-2 \%$ of mature cystic teratoma of the ovary (MCTO) undergo malignant transformation, of which $80 \%$ are squamous cell carcinoma (SCC) transformation in MCTO. We aim to investigate the clinical characteristics and treatment of SCC transformation in MCTO

Methods: We systematically searched PubMed database and individual patient data about SCC transformation in MCTO were extracted. The published cases were combined with 6 cases of SCC transformation in MCTO from Qilu Hospital, Shandong University.

Results: The incidence of SCC transformation in MCTO was $0.3 \%$. A total of 435 cases of SCC transformation in MCTO were enrolled in the analysis. The mean age of diagnosis was 53.5 (range 19-87) years old. The most common clinical manifestations were abdominal pain (47.3\%) and abdominal mass (26.0\%). Stagel,II, III and IV accounted for 50.0, 18.8, 26.8 and $4.4 \%$ of all cases, respectively. Patients with stage I had significantly better prognosis than stage II, III and IV patients $(P<0.01)$. Hysterectomy can improve overall survival $(P<0.01)$. For patients younger than 45 years old with stagelA orlC, there was no difference in mortality between fertility-sparing and radical surgery $(P=1.00)$. Adjuvant chemotherapy can improve survival in patients with advanced stage $(P=0$. $02)$, and chemotherapy with platinum was related to better prognosis $(P=0.02)$.

Conclusion: SCC transformation in MCTO is a rare malignancy mainly occurs in older age. FIGO stage is an independent prognostic factor. Hysterectomy and platinum-based chemotherapy are associated with better survival. Fertility-sparing surgery is feasible for young patients with early stage.
\end{abstract}

Keywords: Ovarian cancer, Mature cystic teratoma of the ovary, Squamous cell carcinoma transformation, Survival analysis

\section{Background}

Mature cystic teratoma of the ovary (MCTO) may occur in $10-20 \%$ of women during their lifetime [1]. The biological behavior of MCTO is benign, while $0.17-2 \%$ of MCTO may undergo malignant transformation [2]. There are various histological types of malignant transformation such as squamous cell carcinoma (SCC),

\footnotetext{
* Correspondence: kongbeihua@sdu.edu.cn

${ }^{+}$Congcong Li and Qing Zhang contributed equally to this work.

'Department of Obstetrics and Gynecology, Qilu Hospital, Shandong

University, 107 West Wenhua Road, Ji'nan, Shandong 250012, People's Republic of China

${ }^{2}$ Gynecology Oncology Key Laboratory, Qilu Hospital, Shandong University, Ji'nan, Shandong 250012, People's Republic of China
}

adenocarcinoma, small cell carcinoma, sarcoma, malignant melanoma and mixed histology [3]. Among them SCC transformation in MCTO is most common, accounting for $80 \%$ of all malignant transformation [4].

The clinical manifestations of SCC transformation in MCTO are not specific. Tumor of early stage is often detected accidentally during physical examination or postoperative pathological examination [5], while palpable mass, bloating and abdominal pain are often present in advanced stage [6,7]. Acute abdomen may occur due to tumor torsion or rupture [8]. Moreover, preoperative imaging investigation and laboratory tests are not specific, either.

(c) The Author(s). 2019 Open Access This article is distributed under the terms of the Creative Commons Attribution 4.0 International License (http://creativecommons.org/licenses/by/4.0/), which permits unrestricted use, distribution, and 
Table 1 Summary data from published literatures on SCC transformation in MCTO

\begin{tabular}{|c|c|c|c|c|c|c|c|c|c|c|c|c|}
\hline \multicolumn{13}{|c|}{ a. Case series on SCC transformation in MCTO } \\
\hline \multirow[t]{2}{*}{ Country of study } & \multirow[t]{2}{*}{ Author (year) } & \multirow[t]{2}{*}{ Number of cases } & \multirow[t]{2}{*}{ Age } & \multicolumn{5}{|c|}{ Stage } & \multicolumn{4}{|c|}{ Grade } \\
\hline & & & & 1 & $\|$ & III & IV & NA & 1 & 2 & 3 & NA \\
\hline Japan & Yoshida et al. (2016) & 2 & $37-64$ & & 2 & & & & & & & 2 \\
\hline Japan & Tazo et al. (2016) & 2 & $45-53$ & 2 & & & & & 2 & & & \\
\hline Korea & Park et al. (2015) & 2 & $48-67$ & & 1 & 1 & & & & & & 2 \\
\hline UK & Araujo et al.(2015) & 4 & $35-44$ & 2 & 1 & & 1 & & & 2 & 2 & \\
\hline China & Chiang et al.(2015) & 4 & $32-54$ & 2 & & 2 & & & & & & 4 \\
\hline Turkey & Koc et al. (2015) & 12 & $28-62$ & 8 & 1 & 2 & 1 & & & & & 12 \\
\hline USA & Rojas et al. (2015) & 2 & $55-71$ & & 1 & 1 & & & & 2 & & \\
\hline Korea & Choi et al.(2014) & 4 & $35-51$ & 2 & & 2 & & & & & & 2 \\
\hline Pakistan & Hannan et al. (2014) & 3 & $50-66$ & 2 & & 1 & & & & & 3 & \\
\hline Thailand & Oranratanaphan et al. (2013) & 4 & $34-70$ & 2 & & 2 & & & & & & 4 \\
\hline UK & Powell et al. (2013) & 6 & $42-65$ & & & 4 & 2 & & & & & 6 \\
\hline Turkey & Ulker et al.(2012) & 3 & $43-47$ & 3 & & & & & & & & 3 \\
\hline China & Chiang et al. (2011) & 3 & $32-54$ & 1 & & 2 & & & & 1 & & 2 \\
\hline Japan & Sakuma et al.(2010) & 15 & $29-77$ & 8 & 3 & 3 & 1 & & 5 & 2 & 3 & 5 \\
\hline India & Gupta et al. (2009) & 2 & $30-65$ & 2 & & & & & & 2 & & \\
\hline Korea & Park et al.(2008) & 12 & $29-75$ & 6 & 1 & 5 & & & & & & 2 \\
\hline Japan & Iwasa et al.(2008) & 21 & $32-84$ & 14 & 2 & 4 & 1 & & 6 & 10 & 5 & \\
\hline UK & Hurwitz et al.(2007) & 12 & $27-69$ & 8 & 2 & 2 & & & 1 & 3 & 8 & \\
\hline Japan & Yamaguchi et al.(2007) & 11 & $29-67$ & 7 & 1 & 2 & 1 & & & & & 11 \\
\hline India & Bal et al. (2007) & 4 & $35-45$ & & & & & 4 & & & & 4 \\
\hline Korea & Park et al. (2007) & 5 & $31-75$ & 3 & & 1 & 1 & & & & & 5 \\
\hline USA & Dos Santos et al. (2007) & 17 & $37-75$ & 8 & 5 & 4 & & & & & & 17 \\
\hline Korea & Rim et al. (2006) & 7 & 19-71 & 6 & 1 & & & & 1 & 1 & 2 & 3 \\
\hline China & Wen et al. (2006) & 2 & $32-52$ & 2 & & & & & & 1 & & 1 \\
\hline Thailand & Tangjitgamol et al. (2003) & 4 & $42-74$ & 2 & 1 & 1 & & & & & & 4 \\
\hline Japan & Sumi et al. (2001) & 3 & $53-72$ & 1 & 1 & 1 & & & & & & 3 \\
\hline China & Chen et al. (2001) & 3 & $30-65$ & & 2 & 1 & & & & & & 3 \\
\hline Japan & Hirai et al. (2000) & 3 & $61-72$ & 2 & 1 & & & & & & & 3 \\
\hline Japan & Emoto et al. (2000) & 5 & $39-73$ & & 1 & 5 & & & & & & 5 \\
\hline China & Shen et al. (1998) & 10 & $30-82$ & 2 & 1 & 3 & 2 & 2 & & & & 10 \\
\hline Japan & Yoshioka et al. (1998) & 4 & $41-68$ & 3 & & 1 & & & & & & 4 \\
\hline Japan & Kikkawa et al. (1998) & 37 & $28-87$ & 19 & 5 & 13 & & & 9 & 7 & 6 & 5 \\
\hline China & Tseng et al. (1996) & 26 & $21-77$ & 13 & 2 & 10 & 1 & & 2 & 12 & 12 & \\
\hline Turkey & Zorlu et al. (1996) & 3 & $28-42$ & 3 & & & & & & & & 3 \\
\hline USA & Pins et al. (1996) & 16 & $21-75$ & 7 & 6 & 3 & & & 2 & 7 & 7 & \\
\hline Japan & Hirakawa et al. (1989) & 28 & $32-84$ & 18 & 3 & 5 & 1 & 1 & 14 & 10 & 3 & 1 \\
\hline Japan & Kimura et al. (1989) & 6 & $37-80$ & 2 & 3 & 1 & & & 2 & 3 & 1 & \\
\hline Japan & Kashimura et al. (1989) & 7 & $49-78$ & 5 & 1 & 1 & & & & & & 7 \\
\hline Netherlands & Chadha et al. (1988) & 16 & $35-73$ & 8 & 1 & 5 & 2 & & 8 & 1 & 5 & 2 \\
\hline UK & Ribeiro et al. (1987) & 6 & $25-64$ & & 5 & 1 & & & 1 & & 2 & 3 \\
\hline Japan & Tamaya et al. (1984) & 2 & $30-61$ & & & & 2 & & & & & 2 \\
\hline UK & Stamp et al. (1983) & 18 & $36-76$ & & & & & 18 & & & & 18 \\
\hline
\end{tabular}


Table 1 Summary data from published literatures on SCC transformation in MCTO (Continued)

\begin{tabular}{|c|c|c|c|c|c|c|c|c|c|c|}
\hline Australia & Curling et al. (1979) & 10 & $46-73$ & 6 & 2 & & 6 & 2 & 2 & \\
\hline Spain & Amerigo et al. (1978) & 5 & $42-59$ & 2 & 2 & 1 & & & & 5 \\
\hline USA & Krumerman et al. (1976) & 4 & $51-65$ & 2 & 1 & & & & & 4 \\
\hline \multicolumn{10}{|c|}{ b. Case reports on SCC transformation in MCTO } & \\
\hline Country of study & Author (year) & & Age & & Stage & & Stage & & & \\
\hline UK & Gooneratne et al. (2015) & & 63 & & $\|$ & & 3 & & & \\
\hline USA & Black et al. (2015) & & 74 & & । & & NA & & & \\
\hline India & Srivastava et al. (2015) & & 60 & & $\|$ & & 2 & & & \\
\hline Greece & Kalampokas et al. (2014) & & 56 & & । & & 1 & & & \\
\hline USA & Yarmohammadi et al. (2014) & & 48 & & III & & 3 & & & \\
\hline India & Patni et al. (2014) & & 53 & & । & & NA & & & \\
\hline Korea & Yun et al. (2013) & & 30 & & । & & 1 & & & \\
\hline Turkey & Balik et al. (2013) & & 66 & & III & & 2 & & & \\
\hline Pakistan & Chaudhry et al. (2013) & & 43 & & । & & 2 & & & \\
\hline India & Mandal et al. (2012) & & 56 & & III & & 1 & & & \\
\hline Turkey & Avci et al. (2012) & & 52 & & । & & 2 & & & \\
\hline USA & Song et al. (2012) & & 73 & & $\|$ & & 1 & & & \\
\hline Serbia & Amidzic et al. (2012) & & 80 & & । & & 1 & & & \\
\hline USA & Baughn et al. (2011) & & 58 & & । & & NA & & & \\
\hline Turkey & Kahraman et al. (2011) & & 63 & & । & & NA & & & \\
\hline India & Prasad et al. (2011) & & 40 & & III & & 1 & & & \\
\hline Nigenia & Badmos et al. (2011) & & 46 & & $\|$ & & NA & & & \\
\hline Japan & Ito et al. (2011) & & 78 & & $\|$ & & NA & & & \\
\hline USA & Parithivel et al. (2011) & & 68 & & $\|$ & & 3 & & & \\
\hline USA & Alatassi et al. (2011) & & 49 & & $\|$ & & NA & & & \\
\hline India & Madan et al. (2010) & & 37 & & । & & 1 & & & \\
\hline Greece & Korkontzelos et al. (2010) & & 56 & & । & & NA & & & \\
\hline Japan & Hosokawa et al. (2010) & & 52 & & । & & NA & & & \\
\hline Germany & Budiman et al. (2010) & & 41 & & । & & 3 & & & \\
\hline Korea & Lim et al. (2009) & & 68 & & III & & NA & & & \\
\hline Iran & Shariat-Torbaghan et al. (2009) & & 63 & & IV & & 3 & & & \\
\hline Brazil & Silva et al. (2009) & & 75 & & । & & 1 & & & \\
\hline China & Wang et al. (2008) & & 39 & & III & & 2 & & & \\
\hline China & Ding et al. (2008) & & 62 & & III & & NA & & & \\
\hline Japan & Mekaru et al. (2008) & & 33 & & । & & NA & & & \\
\hline India & Santwani et al. (2008) & & 40 & & । & & NA & & & \\
\hline Turkey & Arioz et al. (2007) & & 31 & & $\|$ & & 2 & & & \\
\hline UK & Sanghera et al. (2006) & & 48 & & $\|$ & & NA & & & \\
\hline Greece & Filippakis et al. (2006) & & 41 & & । & & NA & & & \\
\hline USA & Spannuth et al. (2005) & & 52 & & $\|$ & & 3 & & & \\
\hline China & Lai et al. (2005) & & 47 & & III & & NA & & & \\
\hline UK & Karanjgaokar et al. (2005) & & 66 & & III & & 2 & & & \\
\hline UK & Mechery et al. (2004) & & 51 & & । & & 3 & & & \\
\hline Japan & Takemori et al. (2003) & & 69 & & $\|$ & & NA & & & \\
\hline USA & Powell et al. (2003) & & 67 & & ॥ा & & NA & & & \\
\hline
\end{tabular}


Table 1 Summary data from published literatures on SCC transformation in MCTO (Continued)

\begin{tabular}{|c|c|c|c|c|}
\hline Canada & Do et al. (2002) & 44 & $\|$ & 2 \\
\hline Canada & Mayer et al. (2002) & 37 & $\|$ & 2 \\
\hline USA & Noumoff et al. (2001) & 36 & 1 & 3 \\
\hline Japan & Takeuchi et al. (2000) & 72 & $\|$ & NA \\
\hline France & Kurtz et al. (1999) & 34 & III & NA \\
\hline Japan & Isoda et al. (1999) & 56 & $\|$ & NA \\
\hline USA & Lee et al. (1999) & 50 & $\|$ & 1 \\
\hline UK & As et al. (1997) & 33 & $\|$ & 2 \\
\hline USA & Griffiths et al. (1995) & 76 & III & 2 \\
\hline USA & Kung et al. (1994) & 44 & । & 3 \\
\hline USA & Rose et al. (1993) & 42 & III & NA \\
\hline USA & Christopherson et al. (1989) & 26 & III & 1 \\
\hline USA & Selim et al. (1984) & 43 & 1 & NA \\
\hline Japan & Mitui et al. (1983) & 72 & III & 1 \\
\hline
\end{tabular}

Large-scale clinical prospective study is not feasible because of the low incidence of SCC transformation in MCTO and the published cases are scattered, and the optimal treatment for SCC transformation in MCTO remains unclear [9]. Some doctors hold the idea that since SCC originates from epithelium so its treatment should follow principles that of epithelial ovarian cancer $[10,11]$, some believe that the treatment should refer to SCC of other sites [12], and some suggest that since the malignancy presents on the basis of MCTO, which is a kind of ovarian germ cell tumors, the treatment can refer to that of ovarian germ cell malignancy. However, the surgical principle and postoperative adjuvant therapy of epithelial ovarian cancer, ovarian germ cell tumors and squamous cell carcinoma are different [13]. So it is of great importance to find out the most effective treatment.

Table 2 Clinical features of SCC transformation in MCTO from a retrospective chart review

\begin{tabular}{|c|c|c|c|c|c|c|c|c|c|c|c|}
\hline Case & $\begin{array}{l}\text { Age } \\
\text { (years) }\end{array}$ & Symptoms & $\begin{array}{l}\text { Elevated tumor } \\
\text { marker }\end{array}$ & $\begin{array}{l}\text { Diameter } \\
(\mathrm{cm})\end{array}$ & Surgery & $\begin{array}{l}\text { Optimal } \\
\text { debulking }\end{array}$ & Rupture & Grade & Stage & $\begin{array}{l}\text { Adjuvant } \\
\text { therapy }\end{array}$ & $\begin{array}{l}\text { Follow- } \\
\text { up } \\
\text { (status, } \\
\text { months) }\end{array}$ \\
\hline 1 & $\geq 45$ & $\begin{array}{l}\text { Accidental } \\
\text { finding }\end{array}$ & - & 7 & $\begin{array}{l}\text { TH + LSO + BPLND + } \\
\text { omentectomy }\end{array}$ & Y & $N$ & 3 & IA & $\mathrm{TC} \times 1$ & LOST, 3 \\
\hline 2 & $\geq 45$ & Pain & $\begin{array}{l}\text { CA125(179.5 U/mL), } \\
\text { CEA }(6.1 \mathrm{ng} / \mathrm{mL})\end{array}$ & 12 & $\begin{array}{l}\mathrm{TH}+\mathrm{BSO}+ \\
\text { omentectomy }+ \\
\text { BPLND + BPALND + } \\
\text { peritoneal tumor } \\
\text { resection }\end{array}$ & Y & $N$ & 2 & $\| B$ & $\mathrm{TC} \times 6$ & NED, 72 \\
\hline 3 & $\geq 45$ & $\begin{array}{l}\text { Pain, } \\
\text { distension }\end{array}$ & $\begin{array}{l}\text { CA125(363.8 U/mL), } \\
\text { CEA }(25.2 \mathrm{ng} / \mathrm{mL})\end{array}$ & 15 & $\begin{array}{l}\mathrm{TH}+\mathrm{BSO}+ \\
\text { appendectomy }\end{array}$ & Y & $N$ & 2 & $\| \mathrm{IIB}$ & $\mathrm{TC} \times 1$ & DOD, 9 \\
\hline 4 & $\geq 45$ & $\begin{array}{l}\text { Pain, } \\
\text { distension, } \\
\text { fever }\end{array}$ & $\begin{array}{l}\text { CA125(62.9 U/mL), } \\
\text { SCC (7.3 ng/mL) }\end{array}$ & 20 & $\begin{array}{l}\mathrm{TH}+\mathrm{BSO}+ \\
\text { omentectomy }+ \\
\text { partial peritoneal } \\
\text { resection }\end{array}$ & $N$ & Preoperative & 2 & $\| I C$ & - & $\begin{array}{l}\text { LOST, } \\
24\end{array}$ \\
\hline 5 & $\geq 45$ & $\begin{array}{l}\text { Pain, } \\
\text { vaginal } \\
\text { bleeding }\end{array}$ & $\begin{array}{l}\text { CA125(144.7 U/mL), } \\
\text { SCC (15.1 ng/mL), } \\
\text { CA199(119.1 U/mL), } \\
\text { CEA }(40.9 \mathrm{ng} / \mathrm{mL})\end{array}$ & 25 & $\begin{array}{l}\mathrm{TH}+\mathrm{BSO}+\text { tumor } \\
\text { resection + } \\
\text { sigmoidectomy }\end{array}$ & $N$ & Intraoperative & 3 & $I I I C$ & - & $\begin{array}{l}\text { DOD } \\
15\end{array}$ \\
\hline 6 & $<45$ & $\begin{array}{l}\text { Accidental } \\
\text { finding }\end{array}$ & $\begin{array}{l}\text { CA125 }(42.8 \mathrm{U} / \mathrm{mL}) \\
\text { CA199(97.1 U/mL) }\end{array}$ & 5 & $\begin{array}{l}\text { Initial surgery: Left } \\
\text { ovarian cystectomy } \\
\text { Restaging surgery: } \\
\text { LSO + omentectomy } \\
\text { + BPLND + BPALND }\end{array}$ & Y & $N$ & 3 & IC & $\mathrm{TC} \times 3$ & NED, 8 \\
\hline
\end{tabular}




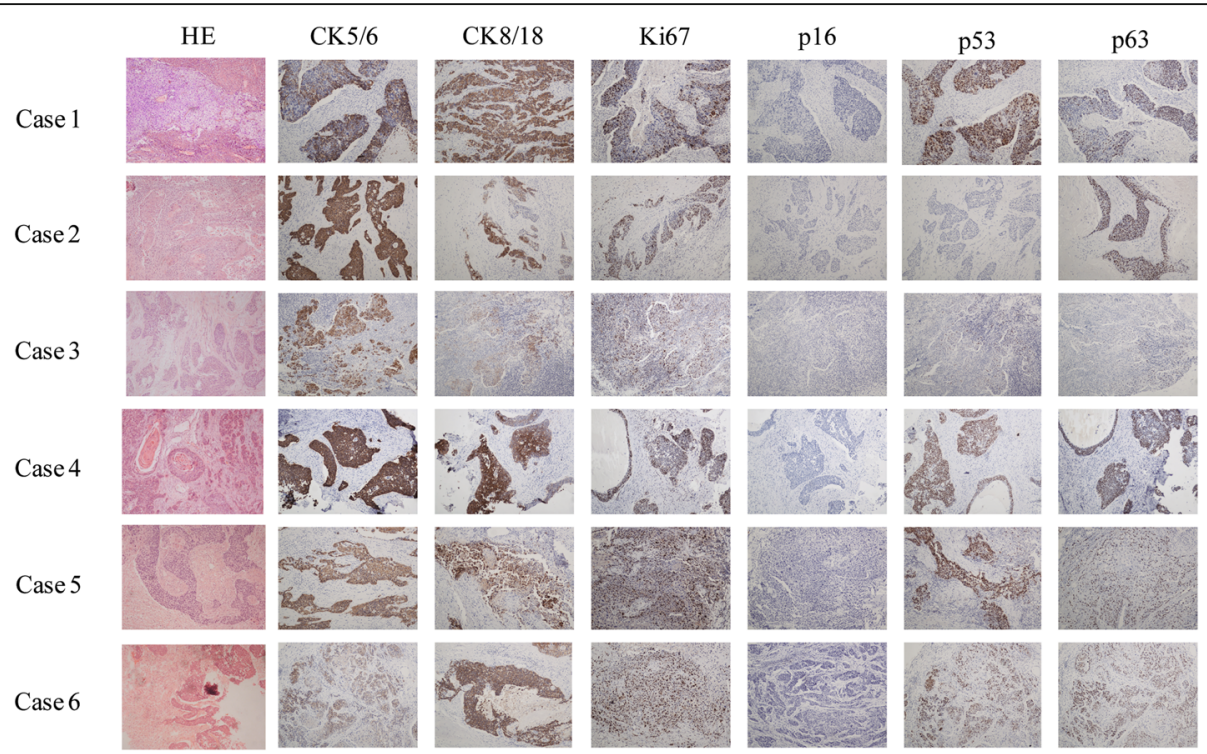

Fig. 1 Histological features of SCC transformation in MCTO from a retrospective chart review

In this study, we systematic review published data about SCC transformation in MCTO from 1977 to 2016 and cases from Qilu Hospital, Shandong University, aiming to further elucidate the clinical characteristics, prognostic factors and treatment of SCC transformation in MCTO and provide evidence of clinical management of this rare malignancy.

\section{Methods}

We searched PubMed database with key words of "squamous cell carcinoma of mature cystic teratoma ovary", "malignant transformation mature teratoma ovary", "second tumor teratoma", "malignant dermoid cyst ovary", "MCTO squamous cell carcinoma", "SCC in MCTO", "mature cystic teratoma malignant". Cases of SCC transformation in MCTO published from January 1977 to October 2016 were included. Only cases with specific histology, invasive behavior and available individual patient data were included (Additional file 1: Figure S1). The MCTO cases of Qilu hospital between January 2005 and October 2016 were reviewed and 6 cases SCC transformation in MCTO were included in this study.
Clinicopathologic information, including age, tumor size, symptoms, stage, histological grade, surgical approach, adjuvant therapy, survival status and follow-up time were collected and analyzed. We used SPSS (version 21.0, for Windows) for statistical analysis. Data analysis was performed with descriptive statistics, chi-square test, Kaplan-Meier plots with Log-rank test, univariate and multivariate Cox proportional hazards regression model. A two-tailed $P<0.05$ value was defined as statistically significant.

\section{Results}

A total of 435 cases were included in this study, with 429 SCC transformation in MCTO cases from 45 case series and 54 case report [3-8, 10-12, 14-103] (Table 1), and 6 cases from Qilu Hospital, Shandong University.

\section{Retrospective chart review}

From January 2005 to October 2016, there were 1836 MCTO cases in Qilu Hospital, Shandong University, 6 cases of them were SCC transformation in MCTO, accounting for $0.3 \%$ of all MCTO cases. Mean age of the 6

Table 3 Immunohistochemical panel of SCC transformation in MCTO from a retrospective chart review

\begin{tabular}{lllllllll}
\hline Antibody & Source & Dilution & Case 1 & Case 2 & Case 3 & Case 4 & Case 5 & Case 6 \\
\hline Ki67 & Abcam & $1: 250$ & ++ & ++ & ++ & ++ & ++ & + \\
p16 & Abcam & $1: 100$ & - & - & + & - & + & + \\
p63 & Abcam & $1: 500$ & + & ++ & ++ & ++ & + & ++ \\
CK8/18 & Dako & prediluted & +++ &,$+++ 5 \%$ & ++ & +++ & +++ & +++ \\
CK5/6 & Dako & prediluted & +++ & ++ & +++ & +++ & ++ & ++ \\
p53 & Abcam & $1: 100$ & + focal & +++ & - & ++ & ++ & ++ \\
\hline
\end{tabular}

The antibody reaction was graded according to the intensity od staining: - (negative), + (weak), ++(moderate), +++ (strong) 
Table 4 Clinical features of SCC transformation in MCTO

\begin{tabular}{|c|c|}
\hline & Results \\
\hline Age, years $(n=434)^{a}$ & $53.5(13.9,19-87)$ \\
\hline$<45$ years & 121 \\
\hline$\geq 45$ years & 313 \\
\hline Tumor size, $\mathrm{cm}(n=316)^{\mathrm{a}}$ & $14.8(5.9,3.5-40)$ \\
\hline \multicolumn{2}{|l|}{ Preoperative tumor markers ${ }^{\mathrm{b}}$} \\
\hline SCC-Ag, ng/mL $(n=78)$ & $7.4(3.0,20.0)$ \\
\hline $\mathrm{CA} 125, \mathrm{U} / \mathrm{mL}(n=104)$ & $64.4(34.2,143.0)$ \\
\hline CA19-9,U/mL $(n=65)$ & $144.0(45.1,943.5)$ \\
\hline CEA, ng/mL $(n=51)$ & $6.9(2.5,23.0)$ \\
\hline \multicolumn{2}{|c|}{ Clinical manifestation $(n=204)$} \\
\hline Abdominal/pelvic pain & 139 \\
\hline Mass & 53 \\
\hline Abdominal bloating & 49 \\
\hline Physical examination & 10 \\
\hline Urinary frequency & 6 \\
\hline Weight loss & 11 \\
\hline Change in bowel habits & 20 \\
\hline Fever & 7 \\
\hline \multicolumn{2}{|l|}{ FIGO staging $(n=414)$} \\
\hline । & 207 \\
\hline$\|$ & 78 \\
\hline III & 111 \\
\hline IV & 18 \\
\hline \multicolumn{2}{|l|}{ Histological grade $(n=203)$} \\
\hline 1 & 54 \\
\hline 2 & 84 \\
\hline 3 & 65 \\
\hline
\end{tabular}

${ }^{\mathrm{a}}$ Mean (SD, range); ${ }^{\mathrm{b}}$ Median (Q25, Q75)

patients was 53.7 (range 26-68) years. Follow-up time was 3-72 months. 2 cases underwent comprehensive staging surgery of ovarian cancer. 1 patient received fertility-sparing surgery. For this patient, the diagnosis of SCC transformation in MCTO in stageIC was made after initial left ovarian tumor resection, and then she received fertility-sparing staging surgery. 3 widespread metastatic cases underwent cytoreductive surgery and 1 of them was optimally debulked (residual tumor volume less than $1 \mathrm{~cm}$ ). 4 cases were treated with postoperative chemotherapy. All of them received TC regimen for 16 cycles. No case was treated with postoperative radiotherapy. Details on clinical characteristics were listed in Table 2.

Imaging investigation indicated cystic-solid mass with blood flow signal and enhancement. Grossly, the tumor consisted of cystic and solid components. There were typical components of MCTO such as hair, oil,
Table 5 Clinical features and overall survival of SCC transformation in MCTO

\begin{tabular}{lll}
\hline Variable & Univariate HR $(95 \% \mathrm{Cl})$ & $P$ value \\
\hline Age $(n=370)$ & & \\
$<45(n=105)$ & Reference & $<0.01^{*}$ \\
$\geq 45(n=265)$ & $1.91(1.26-2.89)$ & \\
Diameter $(\mathrm{cm})(n=265)$ & $(n=265)$ & \\
$\leq 10(n=67)$ & Reference & 0.73 \\
$>10(n=198)$ & $1.08(0.70-1.68)$ & \\
Stage $(n=348)$ & & $<0.01^{*}$ \\
I $(n=172)$ & Reference & $<0.01^{*}$ \\
II $(n=70)$ & $6.92(3.98-12.06)$ & $<0.01^{*}$ \\
III $(n=92)$ & $9.32(5.58-15.59)$ & \\
IV $(n=14)$ & $16.45(7.95-34.02)$ & \\
Grade $(n=169)$ & & 0.17 \\
$1(n=43)$ & Reference & 0.10 \\
$2(n=69)$ & $1.60(0.81-3.15)$ & \\
$3(n=57)$ & $1.76(0.89-3.49)$ &
\end{tabular}

sebaceous glands and epidermis. Microscopically, there were increased layers of squamous epithelium, disorderly arranged cells, squamous cells with atypia, irregular nuclei and necrosis (Fig. 1). All 6 cases were positive staining for $\mathrm{p} 63$, negative staining for $\mathrm{p} 16$, moderate to strong positive staining for Ki67 and alteration in p53. Detailed immunohistochemical panel is listed in Table 3 and Fig. 1.

\section{Systematic review}

Of the 435 cases of SCC transformation in MCTO, follow-up information was available for 363 cases and the follow-up time ranged from 0.4 months to 276 months. 146 (40.2\%) cases ended up with death during the follow-up. Mean age of diagnosis was 53.5 (range $19-87)$ years. 121(27.9\%) were $<45$ year old while 313 (72.1\%) were $\geq 45$ years old (Table 4 ). Age $\geq 45$ years was related with worse prognosis compared with patients $<45(P<0.01)$ (Table 5). Mean tumor size was 14.8 (range $3.5-40.0) \mathrm{cm}$. Overall survival of tumor $\leq 10$ $\mathrm{cm}$ and $>10 \mathrm{~cm}$ were of no difference (Table 5). Median (Q25, Q75) preoperative SCC-Ag was 7.4 $(3.0,20.0) \mathrm{ng} /$ $\mathrm{mL}, \mathrm{CA} 125$ was $64.4(34.2,143.0) \mathrm{U} / \mathrm{mL}, \mathrm{CA} 19-9$ was $144.0(45.1,943.5) \mathrm{U} / \mathrm{mL}$ and CEA was $6.9(2.5,23.0)$ $\mathrm{ng} / \mathrm{mL}$. Abdominal pain and palpable abdominal mass were two major clinical manifestations of SCC transformation in MCTO, occurring in 47.3 and $26 \%$ of all cases, respectively. StageI,II, III and IV accounted for $50.0,18.8,26.8$ and $4.4 \%$ of all cases, respectively (Table $4)$. Compared with stage I, stage II, III and IV were associated with worse prognosis $(P<0.01)$ (Table 5 , Fig. 2 a). 


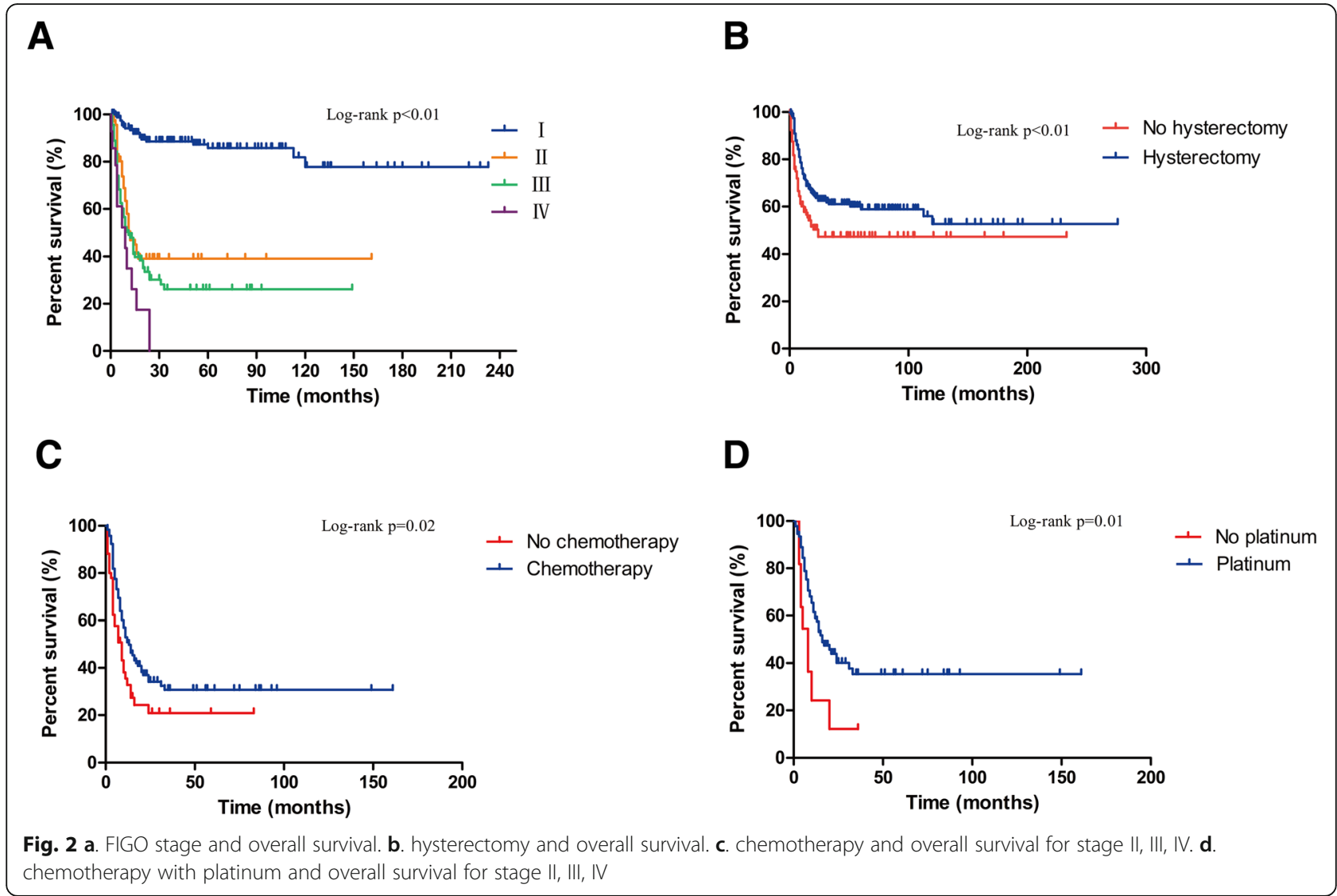

5-year overall survival was 85.8, 39.1, 26.2 and $0 \%$ for stage I, II, III, and IV, respectively. There was no interaction between histology grade and survival (Table 5).

As for treatment, hysterectomy can reduce death risk ( $P$ $<0.01$ ) (Table 6, Fig. 2b) whereas lymphadenectomy did not improve survival. Omentectomy did not improve survival with univariant analysis, while after adjusted with International Federation of Gynecology and Obstetrics (FIGO) stage, omentectomy was associated with better prognosis $(P=0.04)$ (Table 6). 24 of the 51 patients younger than 45 years old with stageIA orlC underwent fertility-sparing surgery. There was no difference in mortality between fertility-sparing and radical surgery $(P=1.00)$.

Efficacy of postoperative adjuvant therapy was analyzed in a subgroup of SCC transformation in MCTO with stage II, III and IV. Adjuvant chemotherapy can improve survival in patients with advanced stage $(P=0.02)$ (Table 7, Fig. 2c), and chemotherapy with platinum was related to better prognosis compared with other drugs $(P=0.02)$ (Table 8, Fig. 2d). However, radiotherapy and chemoradiotherapy did not improve survival (Table 7).

\section{Discussion}

SCC transformation in MCTO is the most common malignant transformation of MCTO [4] and is also the most common cause of SCC of the ovary $[9,104]$. SCC transformation in $\mathrm{MCTO}$ may be a continuous process of squamous metaplasia, atypical hyperplasia, carcinoma in situ, interstitial infiltration and invasive carcinoma $[14,105]$. The mean age of MCTO patients without

Table 6 Surgery modality and overall survival of SCC transformation in MCTO

\begin{tabular}{|c|c|c|c|c|}
\hline Surgery & Univariate HR (95\% Cl) & $P$ value & Stage-adjusted HR (95\% Cl) & $P$ value \\
\hline \multicolumn{5}{|l|}{ Hysterectomy (325) } \\
\hline Yes (232) vs No (93) & $0.60(0.42-0.85)$ & $<0.01^{*}$ & $0.51(0.36-0.74)$ & $<0.01^{*}$ \\
\hline \multicolumn{5}{|l|}{ \Lymphadenectomy (325) } \\
\hline Yes (69) vs No (256) & $0.69(0.43-1.09)$ & 0.11 & $0.76(0.47-1.22)$ & 0.25 \\
\hline \multicolumn{5}{|l|}{ Omentectomy (313) } \\
\hline Yes (120) vs No (193) & $1.04(0.72-1.48)$ & 0.85 & $0.66(0.45-0.98)$ & 0.04 \\
\hline
\end{tabular}


Table 7 Treatments and overall survival of SCC transformation in MCTO of stage II, III and IV

\begin{tabular}{|c|c|c|c|c|}
\hline Treatment & Univariate HR $(95 \% \mathrm{Cl})$ & $P$ value & Stage-adjusted HR (95\% Cl) & $P$ value \\
\hline \multicolumn{5}{|l|}{ Chemotherapy (170) } \\
\hline Yes (118) vs No (52) & $0.60(0.40-0.91)$ & $0.02^{*}$ & $0.56(0.37-0.86)$ & $0.01^{*}$ \\
\hline \multicolumn{5}{|l|}{ Radiotherapy (170) } \\
\hline Yes (50) vs No (120) & $0.80(0.52-1.21)$ & 0.29 & $0.89(0.57-1.38)$ & 0.60 \\
\hline \multicolumn{5}{|l|}{ Chemoradiotherapy (170) } \\
\hline Yes (31) vs No (139) & $0.71(0.43-1.16)$ & 0.17 & $0.73(0.44-1.21)$ & 0.22 \\
\hline
\end{tabular}

Cox proportional hazard regression model analysis

malignant transformation is 32.7 years [1] while the mean age of SCC transformation in MCTO in our study is 53.5 years. Some cases have a history of MCTO [19, 70], suggesting that unmanaged MCTO may undergo malignant transformation. SCC transformation in MCTO may be associated with high-risk human papilloma virus (HPV) infection [15], and alterations in p53 and p16 may be involved in the process of malignant transformation [16, 17, 106]. A recent next-generation sequencing analysis indicated that TP53 mutation was detected in $80 \%$ of SCC transformation in MCTO cases and mutation in TP53 correlated with better prognosis. PIK3CA and CDKN2A were altered in 52 and 44\% cases, respectively [107].

In this study, $50 \%$ of cases are diagnosed in FIGO stage I. The proportion of stage I is much higher than that of all ovarian cancer, which is $15 \%$ [108]. More SCC transformation in MCTO cases can be detected in early stage because the malignant component originates from epithelium of preexistent MCTO [14], which is a gradual process, and is often found unexpectedly after resection of adnexal mass [1]. The same as epithelial ovarian cancer, FIGO stage is an independent prognostic factor for SCC transformation in MCTO. In this study, the 5-year survival rate of stage I patients is $85 \%$, while in patients with stage II, III, the 5-year survival rate is less than $50 \%$. So early detection is of great value and can improve the prognosis of SCC transformation in MCTO.

Comprehensive staging surgery is the standard treatment for ovarian cancer. Hysterectomy and omentectomy appear to improve survival of SCC transformation in MCTO, while lymph node dissection does not affect overall survival in our analysis. This observation suggests that local dissemination is an important metastasis manner of SCC transformation in MCTO. The cases included in this study are retrospective and are from multiple medical centers. What's more, some cases do not point out the exact scope of lymph node dissection. Since lymph node dissection is part of comprehensive staging surgery, we are in favor of performing lymphadenectomy despite the negative result in this study.

For patients with epithelial ovarian cancer in stages IA/IC, unilateral salpingo-oophorectomy is an optional treatment. For patients with malignant ovarian germ cell tumors, regardless of stage, fertility-sparing surgery can be done and after delivery a comprehensive operation should be conducted [13]. Our study suggests that for SCC transformation in MCTO, it is safe and feasible to perform fertility-sparing surgery in patients younger than 45 years of age old with stage IA/IC. There are cases of successful pregnancies after fertility-sparing surgery $[57,74,83]$.

The recommend initial chemotherapy regimen for ovarian germ cell tumor and for epithelial ovarian cancer is bleomycin/etoposide/cisplatin (BEP) and paclitaxel/ carboplatin (TC), respectively. Currently there is no recognized first-line adjuvant therapy for SCC transformation in MCTO, though chemotherapy can improve prognosis of patients with SCC transformation in MCTO of advanced stage. Hackethal et al. suggest that chemotherapy with alkylating agents is related to better prognosis in patients with SCC transformation in

Table 8 Chemotherapy regimen and overall survival of SCC transformation in MCTO of stage II, III and IV

\begin{tabular}{lllll}
\hline Drug $(n=103)$ & Univariate HR $(95 \% \mathrm{Cl})$ & $P$ value & Stage-adjusted HR $(95 \% \mathrm{Cl})$ & $P$ value \\
\hline Platinum derivatives $(n=92)$ & $0.43(0.21-0.87)$ & $0.02^{*}$ & $0.41(0.20-0.84)$ & $1.10(0.60-2.00)$ \\
Taxanes $(n=29)$ & $1.09(0.61-1.98)$ & 0.78 & $0.02^{*}$ \\
Vinca alkaloids $(n=21)$ & $0.59(0.30-1.20)$ & 0.14 & $0.23-1.01)$ & 0.76 \\
Alkylating agents $(n=15)$ & $1.05(0.53-2.09)$ & 0.88 & $0.84(0.38-1.84)$ & 0.05 \\
5-FU $(n=16)$ & $0.77(0.36-1.62)$ & 0.50 & $0.82(0.39-1.75)$ & 0.66 \\
Bleomycin $(n=36)$ & $0.94(0.55-1.61)$ & 0.82 & $0.85(0.48-1.50)$ & 0.61 \\
VP-16 $(n=12)$ & $0.76(0.33-1.78)$ & 0.53 & $0.82(0.35-1.92)$ & 0.57 \\
\hline
\end{tabular}

Cox proportional hazard regression model analysis 
MCTO [109]. However, in our study with the analysis of patients of stage II, III and IV, alkylating agents did not promote overall survival compared with others. We recommend individualized and integrated treatment based on platinum-based chemotherapy.

The histology of SCC transformation in MCTO is squamous cell carcinoma and genetic study indicates that SCC transformation in MCTO has features in common with other SCC [107], which are often sensitive to radiotherapy. However, our results suggested that radiotherapy does not improve prognosis of SCC transformation in MCTO. Whenever applied, doctors should pay attention to complications of radiotherapy [110].

This study has some limitations. Firstly, since the analysis is mostly based on review on published data, we cannot avoid the publication bias. Secondly, although preoperative detection of SCC transformation in MCTO is of great value, in our study we do not conduct the analysis because only a few papers reported the imaging features and serum markers [111, 112]. The size of invasive component, which is possibly related to prognosis, is not available due to the retrospective study design. Moreover, few publications report cycles of chemotherapy, thus we do not investigate the optimal course of treatment. We recommend presentation of such information whenever reporting cases. Lastly, our results should be treated with caution, as the included studies span a prolonged time period ( 40 years) during which changes in medical and therapeutic strategies may have changed.

\section{Conclusions}

SCC transformation in MCTO is a rare malignancy mainly occurs in older age. Early detection is important for better prognosis. Hysterectomy and platinum-based chemotherapy are associated with better survival. Fertility-sparing surgery is feasible for young patients with early stage. Due to the retrospective study design and limited data available, the results should be interpreted with caution. More reports are in need to elucidate the biology of SCC transformation in MCTO.

\section{Additional file}

Additional file 1: Figure S1. The flow chart of study selection and case inclusion. Table S1. Stage of different treatment group in survival analysis. (DOCX $40 \mathrm{~kb}$ )

\section{Abbreviations}

BEP: Bleomycin/etoposide/cisplatin; BPALND: Bilateral para-aortic lymph node dissection; BPLND: Bilateral pelvic lymph node dissection; BSO: Bilateral salpingo-oophorectomy; DOD: Die of disease; FIGO: International Federation of Gynecology and Obstetrics; HPV: Human papilloma virus; HR: Hazard ratio; LSO: Left salpingo-oophorectomy; MCTO: Mature cystic teratoma of the ovary; NED: No evidence of disease; SCC: Squamous cell carcinoma; TC: Paclitaxel/carboplatin; TH: Total hysterectomy

\section{Acknowledgements}

Not applicable.

\section{Funding}

This work was supported by the National Clinical Research Center for Gynecological Oncology (2015BAl13B05), National Natural Science

Foundation of China (81502251), Science and Technology Development Project of Shandong Province (2016GSF201164), National Natural Science Foundation of Shandong Province (BS2014SW009 and 2016ZRE27655). The funding sources had no role in the design of this study and will not have any role during collection, analyses, interpretation of the data, or writing the manuscript.

\section{Availability of data and materials}

The datasets analyzed during this study are accessible in the PubMed repositories. Data of cases from our institution are available in Table 2.

\section{Authors' contributions}

$\mathrm{CL}$ and QZ contributed equally to this work. CL, QZ and BK conceived and designed this study. CL and QZ performed the literature search and study selection. CL, QZ, CQ and ZZ collected all data. SZ, RD and CS performed the immunohistochemistry and summarized the data. $C L$ and $Q Z$ contributed to the data analysis and interpretation of results. $\mathrm{CL}$ drafted the manuscript. QZ and $B K$ revised the manuscript. $C L, Q Z, S Z, R D, C S, C Q, Z Z, X Y$, and $B K$ approved the final version of the manuscript to be published.

\section{Ethics approval and consent to participate}

The study was approved by the Ethics Committees of Qilu Hospital, Shandong University. Written informed consent form for publication will be available for every study participant.

\section{Consent for publication}

Written informed consent was obtained from the patients.

\section{Competing interests}

The authors declare that they have no competing interests.

\section{Publisher's Note}

Springer Nature remains neutral with regard to jurisdictional claims in published maps and institutional affiliations.

Received: 8 February 2018 Accepted: 20 February 2019

Published online: 11 March 2019

\section{References}

1. Kim MJ, Kim NY, Lee DY, Yoon BK, Choi D. Clinical characteristics of ovarian teratoma: age-focused retrospective analysis of 580 cases. Am J Obstet Gynecol. 2011;205(1):32.e31-4.

2. Comerci JT Jr, Licciardi F, Bergh PA, Gregori C, Breen JL. Mature cystic teratoma: a clinicopathologic evaluation of 517 cases and review of the literature. Obstet Gynecol. 1994;84(1):22-8.

3. Rim SY, Kim SM, Choi HS. Malignant transformation of ovarian mature cystic teratoma. International journal of gynecological cancer : official journal of the International Gynecological Cancer Society. 2006;16(1):140-4.

4. Hirakawa T, Tsuneyoshi M, Enjoji M. Squamous cell carcinoma arising in mature cystic teratoma of the ovary. Clinicopathologic and topographic analysis. Am J Surg Pathol. 1989;13(5):397-405

5. Choi EJ, Koo YJ, Jeon JH, Kim TJ, Lee KH, Lim KT. Clinical experience in ovarian squamous cell carcinoma arising from mature cystic teratoma: a rare entity. Obstetrics \& gynecology science. 2014;57(4):274-80.

6. Gooneratne AT, James AO, Gupta J, Abdulaal Y. Squamous cell carcinoma arising in a mature cystic teratoma invading the sigmoid colon: a rare presentation BMJ case reports. 2015;2015:bcr2014208472.

7. Yarmohammadi H, Mansoori B, Wong V, Tacher V, Wilkins LR, Pavlidakey PG, Haaga JR. Squamous cell carcinoma arising from ovarian mature cystic teratoma and causing small bowel obstruction. J Cancer Res Ther. 2014; 10(3):770-2

8. Park JY, Kim DY, Kim JH, Kim YM, Kim YT, Nam JH. Malignant transformation of mature cystic teratoma of the ovary: experience at a single institution. Eur J Obstet Gynecol Reprod Biol. 2008;141(2):173-8. 
9. Glasspool RM, Gonzalez Martin A, Millan D, Lorusso D, Avall-Lundqvist E, Hurteau JA, Davis A, Hilpert F, Kim JW, Alexandre J, et al. Gynecologic Cancer InterGroup (GCIG) consensus review for squamous cell carcinoma of the ovary. International journal of gynecological cancer : official journal of the International Gynecological Cancer Society. 2014;24(9 Suppl 3):S26-9.

10. Sakuma M, Otsuki T, Yoshinaga K, Utsunomiya H, Nagase S, Takano T, Niikura $\mathrm{H}$, Ito K, Otomo K, Tase T, et al. Malignant transformation arising from mature cystic teratoma of the ovary: a retrospective study of 20 cases. International journal of gynecological cancer : official journal of the International Gynecological Cancer Society. 2010;20(5):766-71.

11. Oranratanaphan S, Khemapech N. Characteristics and treatment outcomes of patients with malignant transformation arising from mature cystic teratoma of the ovary: experience at a single institution. Asian Pacific journal of cancer prevention : APJCP. 2013;14(8):4693-7.

12. Dos Santos L, Mok E, lasonos A, Park K, Soslow RA, Aghajanian C, Alektiar K, Barakat RR, Abu-Rustum NR. Squamous cell carcinoma arising in mature cystic teratoma of the ovary: a case series and review of the literature. Gynecol Oncol. 2007;105(2):321-4.

13. Network. NCC: NCCN Clinical Practice Guidelines in Oncology: Ovarian Cancer (Including Fallopian Tube Cancer and Primary Peritoneal Cancer). Version 12017.

14. Pins MR, Young RH, Daly WJ, Scully RE. Primary squamous cell carcinoma of the ovary. Report of 37 cases. Am J Surg Pathol. 1996;20(7):823-33.

15. Chiang AJ, Chen DR, Cheng JT, Chang TH. Detection of human papillomavirus in squamous cell carcinoma arising from dermoid cysts. Taiwanese journal of obstetrics \& gynecology. 2015;54(5):559-66.

16. Iwasa A, Oda Y, Kurihara S, Ohishi Y, Yasunaga M, Nishimura I, Takagi E, Kobayashi H, Wake N, Tsuneyoshi M. Malignant transformation of mature cystic teratoma to squamous cell carcinoma involves altered expression of p53- and p16/Rb-dependent cell cycle regulator proteins. Pathol Int. 2008:58(12):757-64.

17. Yoshioka T, Tanaka T. Immunohistochemical and molecular studies on malignant transformation in mature cystic teratoma of the ovary. J Obstet Gynaecol Res. 1998;24(2):83-90.

18. Koc S, Tapisiz OL, Turan T, Ocalan R, Ozfuttu A, Boran N, Kose MF, Tulunay HG. Malignant transformation of mature cystic teratoma of the ovary: a case series. Journal of experimental therapeutics \& oncology. 2015;11(1):11-6.

19. Yamaguchi K, Mandai M, Fukuhara K, Higuchi T, Hamanishi J, Takakura K, Fujii S. Malignant transformation of mature cystic teratoma of the ovary including three cases occurring during follow-up period. Oncol Rep. 2008; 19(3):705-11.

20. Rojas CP, Ganjei-Azar P, Garcia-Buitrago MT. Unexpected malignant diagnosis in colonic biopsies: malignant transformation of ovarian mature Teratomas-two case reports and review of the literature. Case reports in pathology. 2015;2015:905462.

21. Avci S, Selcukbiricik F, Bilici A, Ozkan G, Ozagari AA, Borlu F. Squamous cell carcinoma arising in a mature cystic teratoma. Case Rep Obstet Gynecol. 2012;2012:314535.

22. Chiang AJ, La V, Peng J, Yu KJ, Teng NN. Squamous cell carcinoma arising from mature cystic teratoma of the ovary. International journal of gynecological cancer : official journal of the International Gynecological Cancer Society. 2011;21(3):466-74.

23. Balik G, Ustuner I, Bedir R, Ural UM, Kagitci M, Guven ES. Appendix and uterus metastasis of squamous cell carcinoma arising from mature cystic teratoma of the ovary. Case Rep Obstet Gynecol. 2013;2013:474891.

24. Ribeiro G, Hughesdon P, Wiltshaw E. Squamous carcinoma arising in dermoid cysts and associated with hypercalcemia: a clinicopathologic study of six cases. Gynecol Oncol. 1988;29(2):222-30.

25. Amerigo J, Nogales FF Jr, Fernandez-Sanz J, Oliva H, Velasco A. Squamous cell neoplasms arising from ovarian benign cystic teratoma. Gynecol Oncol. 1979;8(3):277-83.

26. Curling OM, Potsides PN, Hudson CN. Malignant change in benign cystic teratoma of the ovary. Br J Obstet Gynaecol. 1979;86(5):399-402.

27. Mitui AH, Fujita R, Sugata F, Kienebuchi M, Suzuki K, Sagawa F. A case of ovarian dermoid cyst with malignant transformation perforated into the rectosigmoid colon and small intestine. Endoscopy. 1983;15(5):331-3.

28. Selim MA, Razi A, Lankerani M. Squamous cell carcinoma arising from ovarian benign cystic teratoma. Am J Obstet Gynecol. 1984;150(6):790-2.

29. Tamaya T, Ito M, Fujimoto J, Okada H. Ovarian squamous cell carcinoma derived from a dermoid cyst presenting as vaginal metastasis and the implication of its steroid receptor levels--two case reports. Gynecol Oncol. 1986;23(1):44-50.
30. Chadha S, Schaberg A. Malignant transformation in benign cystic teratomas: dermoids of the ovary. Eur J Obstet Gynecol Reprod Biol. 1988;29(4):329-38.

31. Kimura T, Inoue M, Miyake A, Tanizawa O, Oka Y, Amemiya K, Mineta H, Neki $\mathrm{R}$, Nishino $\mathrm{H}$, Morishige $\mathrm{K}$, et al. The use of serum TA-4 in monitoring patients with malignant transformation of ovarian mature cystic teratoma. Cancer. 1989:64(2):480-3.

32. Rose PG, Tak WK, Reale FR. Squamous cell carcinoma arising in a mature cystic teratoma with metastasis to the paraaortic nodes. Gynecol Oncol. 1993;50(1):131-3.

33. Griffiths D, Wass J, Look K, Sutton G. Malignant degeneration of a mature cystic teratoma five decades after discovery. Gynecol Oncol. 1995;59(3):427-9.

34. Tseng CJ, Chou HH, Huang KG, Chang TC, Liang CC, Lai CH, Soong YK, Hsueh S, Pao CC. Squamous cell carcinoma arising in mature cystic teratoma of the ovary. Gynecol Oncol. 1996;63(3):364-70.

35. Zorlu CG, Kuscu E, Soysal ME, Caglar T, Aydogdu T, Cobanoglu O, Alaybeyoglu T, Gokmen O. Malignant degeneration of mature cystic teratomas. Aust N Z J Obstet Gynaecol. 1996;36(2):221-2.

36. As AK, Webb JB, Wijesinghev D. Advanced squamous cell carcinoma developing in a mature cystic teratoma (dermoid) of the ovary in a young woman: a diagnostic and therapeutic challenge. Journal of obstetrics and gynaecology : the journal of the Institute of Obstetrics and Gynaecology. 1997;17(6):598-9.

37. Kikkawa F, Nawa A, Tamakoshi K, Ishikawa H, Kuzuya K, Suganuma N, Hattori $\mathrm{S}$, Furui $\mathrm{K}$, Kawai M, Arii Y. Diagnosis of squamous cell carcinoma arising from mature cystic teratoma of the ovary. Cancer. 1998;82(11):2249-55.

38. Kurtz JE, Jaeck D, Maloisel F, Jung GM, Chenard MP, Dufour P. Combined modality treatment for malignant transformation of a benign ovarian teratoma. Gynecol Oncol. 1999;73(2):319-21.

39. Isoda H, Setoh H, Oka A, Itagaki Y, Ha-Kawa SK, Harima K, Sawada S, Kayama F. Squamous cell carcinoma arising in a mature teratoma with metastasis to the urinary bladder. Computerized medical imaging and graphics : the official journal of the Computerized Medical Imaging Society. 1999;23(4): 223-5.

40. Lee YC, Abulafia O, Montalto N, Holcomb K, Matthews R, Golub RW. Malignant transformation of an ovarian mature cystic teratoma presenting as a rectal mass. Gynecol Oncol. 1999;75(3):499-503.

41. Takeuchi K, Murata K, Funaki K, Kitazawa S, Kitazawa R. Immunohistochemical detection of parathyroid hormone-related protein in a squamous cell carcinoma arising from mature cystic teratoma causing humoral hypercalcemia of malignancy. Gynecol Oncol. 2000;79(3):504-7.

42. Hirai K, Ishiko O, Itoh F, Nakagawa E, Kanaoka Y, Sumi T, Ogita S. Clinical evaluation of mature teratomas containing malignant elements. Oncol Rep. 2000;7(3):655-7.

43. Emoto M, Obama H, Horiuchi S, Miyakawa T, Kawarabayashi T. Transvaginal color Doppler ultrasonic characterization of benign and malignant ovarian cystic teratomas and comparison with serum squamous cell carcinoma antigen. Cancer. 2000;88(10):2298-304.

44. Sumi T, Ishiko O, Yoshida H, Hyun Y, Nakagawa E, Hirai K, Matsumoto Y, Ogita S. Expression of cyclooxygenase-2 in ovarian mature cystic teratomas with malignant transformation. Int J Mol Med. 2001;8(5):495-8.

45. Do VT, Thomas GM, Bjarnason GA. Postoperative concurrent chronomodulated 5-fluorouracil/leucovorin infusion and pelvic radiotherapy for squamous cell carcinoma of the ovary arising from mature cystic teratoma. International journal of gynecological cancer : official journal of the International Gynecological Cancer Society. 2001;11(5):418-21.

46. Chen RJ, Huang PT, Lin MC, Huang SC, Chow SN, Hsieh CY. Advanced stage squamous cell carcinoma arising from mature cystic teratoma of the ovary. Acta Obstet Gynecol Scand. 2001;80(1):84-6.

47. Mayer C, Miller DM, Ehlen TG. Peritoneal implantation of squamous cell carcinoma following rupture of a dermoid cyst during laparoscopic removal. Gynecol Oncol. 2002;84(1):180-3.

48. Tangjitgamol S, Manusirivithaya S, Sheanakul C, Leelahakorn S, Thawaramara T, Jesadapatarakul S. Squamous cell carcinoma arising from dermoid cyst: case reports and review of literature. International journal of gynecological cancer : official journal of the International Gynecological Cancer Society. 2003;13(4):558-63.

49. Takemori M, Nishimura R. MRI findings of an ovarian dermoid cyst with malignant transformation. Magnetic resonance in medical sciences: MRMS : an official journal of Japan Society of Magnetic Resonance in Medicine. 2003;2(2):105-8 
50. Powell JL, Stinson JA, Connor GP, Shiro BS, Mattison M. Squamous cell carcinoma arising in a dermoid cyst of the ovary. Gynecol Oncol. 2003;89(3): 526-8.

51. Mechery J, Adeyemi O. Squamous cell carcinoma arising in a mature teratoma. Journal of obstetrics and gynaecology : the journal of the Institute of Obstetrics and Gynaecology. 2004;24(2):195-6.

52. Spannuth WA, Rocconi RP, Kirby TO, Huh WK, Conner MG. Gamma mode of infiltration associated with poor prognosis in malignant teratoma of the ovary: a case report. Gynecol Oncol. 2005;98(1):155-7.

53. Lai PF, Hsieh SC, Chien JC, Fang CL, Chan WP, Yu C. Malignant transformation of an ovarian mature cystic teratoma: computed tomography findings. Arch Gynecol Obstet. 2005;271(4):355-7.

54. Karanjgaokar $V$, Booth $A D$, Poole DR. Unusual presentation of squamous cell carcinoma in ovarian dermoid. Journal of obstetrics and gynaecology : the journal of the Institute of Obstetrics and Gynaecology. 2005;25(6):618-9.

55. Sanghera P, El Modir A, Simon J. Malignant transformation within a dermoid cyst: a case report and literature review. Arch Gynecol Obstet. 2006;274(3): $178-80$.

56. Park SB, Kim JK, Kim KR, Cho KS. Preoperative diagnosis of mature cystic teratoma with malignant transformation: analysis of imaging findings and clinical and laboratory data. Arch Gynecol Obstet. 2007;275(1):25-31.

57. Yun NR, Park JW, Hyun MK, Park JH, Choi SJ, Song E. Squamous cell carcinoma arising in an ovarian mature cystic teratoma complicating pregnancy. Obstetrics \& gynecology science. 2013;56(2):121-5.

58. Kalampokas E, Boutas I, Kairi-Vasilatou E, Salakos N, Panoulis K, Aravantinos L, Damaskos C, Kalampokas T, Deligeoroglou E. A rare case report of squamous-cell carcinoma arising from mature cystic teratoma of ovary. ॥ Giornale di chirurgia. 2014;35(9-10):241-5.

59. Mandal S, Badhe BA. Malignant transformation in a mature teratoma with metastatic deposits in the omentum: a case report. Case reports in pathology. 2012;2012:568062

60. Madan M, Bhagat R, Agarwal AP, Sharma S. Squamous cell carcinoma arising in mature cystic teratoma: a rare case. Indian J Cancer. 2010;47(3):346-7.

61. Korkontzelos I, Stamatopoulos C, Antoniou N, Zagaliki A, Demou A, Bakolas G. Malignant transformation of ovarian mature cystic teratoma in a postmenopausal woman presented as acute abdomen. Arch Gynecol Obstet. 2010;281(1):177-9.

62. Baughn MR, Plaxe SC, Weidner N. Primary squamous carcinoma of the ovary likely arising from a monodermal cystic mucinous teratoma. Ann Diagn Pathol. 2011;15(6):446-9.

63. Yoshida K, Kajiyama H, Utsumi F, Mitsui H, Shibata K, Kikkawa F. Radiotherapy for persistent malignant transformation from mature cystic teratoma of the ovary. J Obstet Gynaecol Res. 2016.

64. Song W, Conner M. Squamous cell carcinoma arising within a mature cystic teratoma with invasion into the adjacent small intestine: a case report. International journal of gynecological pathology : official journal of the International Society of Gynecological Pathologists. 2012;31(3):272-5.

65. Hosokawa T, Sato Y, Seki T, Maebara M, Ito K, Kuribayashi S. Malignant transformation of a mature cystic teratoma of the ovary with rupture. Jpn J Radiol. 2010;28(5):372-5.

66. Lim MC, Jung DC, Park SY. Enterovascular fistula in a patient with squamous cell carcinoma arising in a cystic teratoma. South Med J. 2009;102(5):553-4.

67. Shariat-Torbaghan S, Emami-Aleagha M, Sedighi S, Azadbakht F, Keshvari A, Hajarizadeh B, Rosai J. Squamous cell carcinoma arising in an ovarian mature cystic teratoma: a case report. Archives of Iranian medicine. 2009; 12(2):186-9.

68. Kahraman K, Cetinkaya SE, Kankaya D, Dunder I, Soylemez F. Squamous cell carcinoma arising from mature cystic teratoma of the ovary with synchronous endometrial adenocarcinoma. J Obstet Gynaecol Res. 2011; 37(2):146-50.

69. Hurwitz JL, Fenton A, McCluggage WG, McKenna S. Squamous cell carcinoma arising in a dermoid cyst of the ovary: a case series. BJOG : an international journal of obstetrics and gynaecology. 2007;114(10):1283-7.

70. Prasad S, Suguna BV, Ravindra S. Bilateral ovarian squamous cell carcinoma with an antecedent dermoid cyst in the left ovary. J Obstet Gynaecol Res. 2011;37(9):1238-40.

71. Araujo IB, Pinheiro MV, Zanvettor PH, Studart EJ, Filho DF, Coupland SE. High frequency of malignant transformation of ovarian mature Teratoma into squamous cell carcinoma in Young patients in Northeast Brazil. International journal of gynecological pathology : official journal of the International Society of Gynecological Pathologists. 2016;35(2):176-84.
72. Wang PC, Yang TL, Pan HB. CT images of a malignant-transformed ovarian mature cystic teratoma with rupture: a case report. Korean J Radiol. 2008; 9(5):458-61.

73. Black JD, Roque DM, Pasternak MC, Buza N, Rutherford TJ, Schwartz PE, McCarthy S, Ratner E. A series of malignant ovarian cancers arising from within a mature cystic teratoma: a single institution experience. International journal of gynecological cancer : official journal of the International Gynecological Cancer Society. 2015;25(5):792-7.

74. Budiman HD, Burges A, Ruhl IM, Friese K, Hasbargen U. Squamous cell carcinoma arising in a dermoid cyst of the ovary in pregnancy. Arch Gynecol Obstet. 2010;281(3):535-7.

75. Badmos KB, Ibrahim OK, Aboyeji AP, Omotayo JA. Squamous cell carcinoma arising in a mature cystic ovarian teratoma with bladder invasion: a case report. Afr Health Sci. 2011;11(2):285-7.

76. Chaudhry S, Hussain R. Squamous cell carcinoma arising in mature cystic teratoma (dermoid cyst)--a rare presentation. JPMA The Journal of the Pakistan Medical Association. 2013;63(4):521-3.

77. Ito Y, Morikawa S, Kato S, Kajiyama H, Nawa A, Kikkawa F. Carbon ion radiotherapy for recurrent malignant transformation from mature cystic teratoma of the ovary. J Obstet Gynaecol Res. 2012;38(5):880-3.

78. Amidzic J, Dolai M, Kacanski MM, Gluhovic A, Ilic J, Bozanic S. Squamous cell carcinoma in mature cystic teratoma of the ovary. Med Pregl. 2012;65(9-10): 429-31.

79. Parithivel K, Jagannathan JP, Krajewski K, O'Regan K, Quick CM, Ramaiya N, Campos S. Ovarian squamous cell carcinoma arising from mature cystic teratoma. Cancer imaging : the official publication of the International Cancer Imaging Society. 2011;11:67-9.

80. Tazo Y, Yoshimura Y, Shoda T, Kyushima N, Okada T, Yamazaki H. Relevance of frozen sections and serum markers in invasive squamous cell carcinoma arising from ovarian mature cystic teratoma: two case reports. J Med Case Rep. 2016;10:20.

81. Ulker V, Numanoglu C, Akbayir O, Akyol A, Tuncel A, Akca A, Aydin O. Malignant transformation arising from mature cystic teratoma of the ovary: a report of six cases. J Obstet Gynaecol Res. 2012;38(5):849-53.

82. Ding DC, Chu TY, Hsu YH. Multimodality therapy of squamous cell carcinoma arising in mature cystic teratoma of ovary: a case report. Eur J Obstet Gynecol Reprod Biol. 2008;137(2):250-1.

83. Mekaru K, Kamiyama S, Masamoto H, Yagi C, Hirakawa M, Inamine M, Nagai Y, Sakumoto K, Aoki Y. Squamous cell carcinoma arising in an ovarian mature cystic teratoma complicating pregnancy: a case report. Arch Gynecol Obstet. 2008;278(3):287-90

84. Patni R. Squamous cell carcinoma arising in mature cystic teratoma of ovary. Journal of mid-life health. 2014;5(4):195-7.

85. Srivastava P, Dawson L, Mandal AK. Squamous cell carcinoma arising in mature cystic teratoma with sigmoid invasion. J Cancer Res Ther. 2015;11(4): 1024.

86. Santwani PM, Trivedi DP, Vachhani JH, Trivedi NJ. Coexistence of squamous cell carcinoma with dermoid cyst of ovary. Indian J Pathol Microbiol. 2008; 51(1):81-2.

87. Arioz DT, Tokyol C, Sahin FK, Koker G, Yilmaz S, Yilmazer M, Ozalp S. Squamous cell carcinoma arising in a mature cystic teratoma of the ovary in young patient with elevated carbohydrate antigen 19-9. Eur J Gynaecol Oncol. 2008:29(3):282-4.

88. da Silva BB, dos Santos AR, Lopes-Costa PV, Sousa-Junior EC, Correa-Lima MV, Pires CG. Ovarian dermoid cyst with malignant transformation and rupture of the capsule associated with chemical peritonitis: a case report and literature review. Eur J Gynaecol Oncol. 2009;30(2):226-8.

89. Alatassi H, Moghadamfalahi M. Squamous cell carcinoma of the rectum, primary or metastatic? Journal of gastrointestinal oncology. 2011;2(4):262-4.

90. Wen KC, Hu WM, Twu NF, Chen P, Wang PH. Poor prognosis of intraoperative rupture of mature cystic teratoma with malignant transformation. Taiwanese journal of obstetrics \& gynecology. 2006;45(3): 253-6.

91. Filippakis GM, Lagoudianakis EE, Genetzakis M, Antonakis P, Papadima A, Boussiotou A, Katergiannakis V, Manouras A. Squamous cell carcinoma arising in a mature cystic teratoma of the ovary with synchronous invasive lobular breast cancer: case report. Eur J Gynaecol Oncol. 2006;27(5):537-40.

92. Christopherson WA, Councell RB. Malignant degeneration of a mature ovarian teratoma. International journal of gynaecology and obstetrics: the official organ of the International Federation of Gynaecology and Obstetrics. 1989;30(4):379-84 
93. Kashimura M, Shinohara M, Hirakawa T, Kamura T, Matsukuma K. Clinicopathologic study of squamous cell carcinoma of the ovary. Gynecol Oncol. 1989;34(1):75-9.

94. Kung E, Parham GP. Primary lymphatic dissemination of malignant elements in a mature cystic ovarian teratoma. Gynecol Oncol. 1995;57(2):250-3.

95. Gupta V, Sood N. Squamous cell carcinoma arising in a mature cystic teratoma. Indian J Pathol Microbiol. 2009;52(2):271-3.

96. Hannan A, Awan UE, Siddiqui N, Muzaffar N. Malignant transformations in ovarian teratomas: a report of four cases. JPMA The Journal of the Pakistan Medical Association. 2014;64(8):946-8.

97. Shen DH, Khoo US, Xue WC, Cheung AN. Ovarian mature cystic teratoma with malignant transformation. An interphase cytogenetic study. International journal of gynecological pathology : official journal of the International Society of Gynecological Pathologists. 1998;17(4):351-7.

98. Stamp GW, McConnell EM. Malignancy arising in cystic ovarian teratomas. A report of 24 cases. Br J Obstet Gynaecol. 1983;90(7):671-5.

99. Bal A, Mohan H, Singh SB, Sehgal A. Malignant transformation in mature cystic teratoma of the ovary: report of five cases and review of the literature. Arch Gynecol Obstet. 2007;275(3):179-82.

100. Krumerman MS, Chung A. Squamous carcinoma arising in benign cystic teratoma of the ovary: a report of four cases and review of the literature. Cancer. 1977;39(3):1237-42

101. Powell JR, Haldar K. Squamous cell carcinoma arising in a mature cystic Teratoma of the ovary - a case series and review of the literature. European Oncology \& Haematology. 2013;9(1):17-20.

102. Noumoff JS, LiVolsi VA, Deger RB, Montone KT, Faruqi SA. Chromosome analysis and comparison of the benign cystic and malignant squamous component of an ovarian teratoma. Cancer Genet Cytogenet. 2001;125(1): 59-62.

103. Park $\mathrm{CH}$, Jung $\mathrm{MH}$, Ji Yl. Risk factors for malignant transformation of mature cystic teratoma. Obstetrics \& gynecology science. 2015;58(6):475-80.

104. Nasioudis D, Sisti G, Kanninen TT, Holcomb K, Di Tommaso M, Fambrini M, Witkin SS. Epidemiology and outcomes of squamous ovarian carcinoma; a population-based study. Gynecol Oncol. 2016;141(1):128-33.

105. Iwasa A, Oda Y, Kaneki E, Ohishi Y, Kurihara S, Yamada T, Hirakawa T, Wake $\mathrm{N}$, Tsuneyoshi M. Squamous cell carcinoma arising in mature cystic teratoma of the ovary: an immunohistochemical analysis of its tumorigenesis. Histopathology. 2007:51(1):98-104.

106. Fujii T, Oguni S, Kikuchi M, Kanai N, Saito K. p53 mutation in carcinomas arising in ovarian cystic teratomas. Pathol Int. 1995;45(9):649-54.

107. Cooke SL, Ennis D, Evers L, Dowson S, Chan MY, Paul J, Hirschowitz L, Glasspool RM, Singh N, Bell S, et al. The Driver Mutational Landscape of Ovarian Squamous Cell Carcinomas Arising in Mature Cystic Teratoma. Clin Cancer Res. 2017;23(24):7633-7640.

108. Siegel RL, Miller KD, Jemal A. Cancer statistics, 2016. CA Cancer J Clin. 2016; 66(1):7-30.

109. Hackethal A, Brueggmann D, Bohlmann MK, Franke FE, Tinneberg HR, Munstedt K. Squamous-cell carcinoma in mature cystic teratoma of the ovary: systematic review and analysis of published data. The Lancet Oncology. 2008;9(12):1173-80.

110. Lim SC, Choi SJ, Suh CH. A case of small cell carcinoma arising in a mature cystic teratoma of the ovary. Pathol Int. 1998;48(10):834-9.

111. Mori Y, Nishii H, Takabe K, Shinozaki H, Matsumoto N, Suzuki K, Tanabe H, Watanabe A, Ochiai K, Tanaka T. Preoperative diagnosis of malignant transformation arising from mature cystic teratoma of the ovary. Gynecol Oncol. 2003;90(2):338-41.

112. Zissin R. CT diagnosis of malignant degeneration of an ovarian teratoma. Gynecol Oncol. 2000;77(3):482.

\section{Ready to submit your research? Choose BMC and benefit from:}

- fast, convenient online submission

- thorough peer review by experienced researchers in your field

- rapid publication on acceptance

- support for research data, including large and complex data types

- gold Open Access which fosters wider collaboration and increased citations

- maximum visibility for your research: over $100 \mathrm{M}$ website views per year

At BMC, research is always in progress.

Learn more biomedcentral.com/submissions 